\title{
BENTUK DAN MAKNA MEME BERBAHASA ARAB DALAM MEDIA SOSIAL INSTAGRAM SHUWARUN MUDHCHIKATUN
}

\author{
Astarini Arlita Sari \\ astarini.as@student.uns.ac.id \\ Arifuddin \\ arifuddin@staff.uns.ac.id \\ Program Studi Sastra Arab \\ Fakultas Ilmu Budaya \\ Universitas Sebelas Maret Surakarta
}

\begin{abstract}
This paper examines the forms of Arabic meme based on lingual and visual aspect and meaning of rage face in social media Instagram Shuwarun Mudhchikatun. The data used in this paper are taken from social media InstagramShuwarun Mudhchikatun in the period June - July 2015. This research applied qualitative research methods which divided into three steps. First, collecting data through observation method with uninvolved conversation observation technique and noting technique. Second, analyzing data by distribution method with direct segmenting constituents technique and taxonomy technique. Third, presenting data by informal technique. This research concludes that the forms of Arabic meme in social media InstagramShuwarun Mudhchikatunbased is divided to lingual and visual aspect. The lingual aspect consists of word, phrase, clause, and sentence. In addition, form of combination grammatical units such as word and phrase, phrase and word, phrase and clause, and phrase and sentence. Form of Arabic meme based on the visual aspect found consist of icon, icon and index, icon and symbol, and icon, index, and symbol. As for the meaning of rage face in social media InstagramShuwarun Mudhchikatunconsistof five meaning. They arejoy, sadness, anger, surprise and neutral.
\end{abstract}

Keywords: Meme, Standard Arabic, Lingual Units, Semiotics.

$$
\begin{aligned}
& \text { الملخص } \\
& \text { يتناول هذا البحث أشكال ميمي العربية على أساس لغوي وبصري ، ومعاني رمز الوجه (face rage) في وسائل }
\end{aligned}
$$

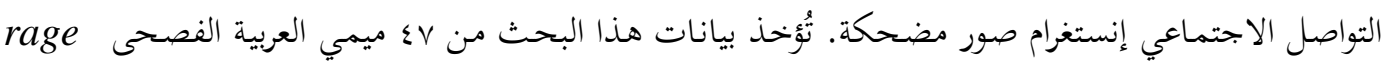

$$
\begin{aligned}
& \text { comics } \\
& \text { يوليو } 10 \text { • ب م. استخدم هذا البحث منهج البحث الوصفي الذى انقسم إلى ثلاث خطوات : أولا، جمع البيانات }
\end{aligned}
$$

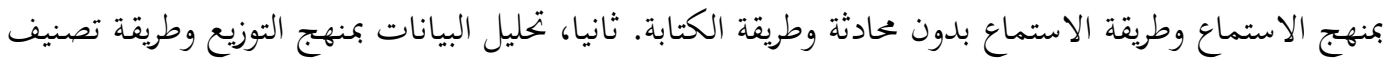

$$
\begin{aligned}
& \text { العناصر المباشر والطريقة التصنيفية. ثالثا، تقديم نتائج البيانات بمنهج غير رسمي. وأظهر هذا البحثث أن أن أشكال }
\end{aligned}
$$

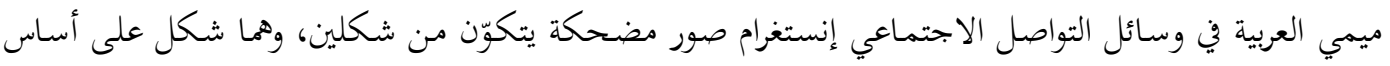

$$
\begin{aligned}
& \text { لغوي وشكل على أساس بصري. الشكل الأول يحتوى على الوحدات اللغوية المنفردة مثل الكلمة والعبارة والجميلة }
\end{aligned}
$$

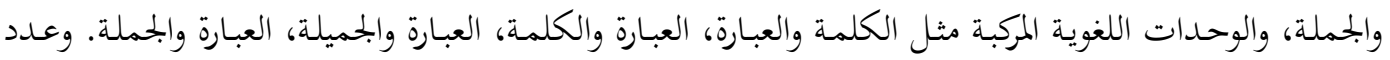




$$
\begin{aligned}
& \text { أشكال الكلمة خمسة بيانات، و أشكال العبارة ثلاث وعشرون بيانا، و أشكال الجميلة ثلاثة بيانات، و أشكال }
\end{aligned}
$$

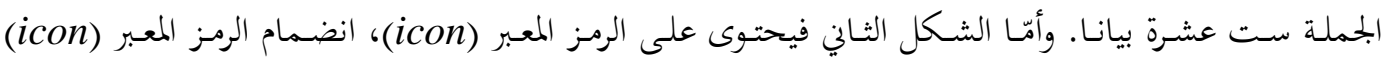

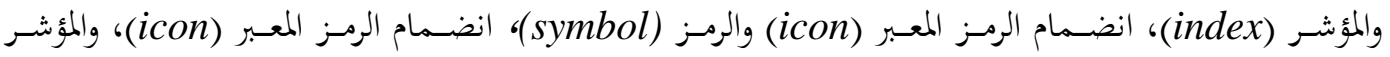

$$
\begin{aligned}
& \text { (rage face) (index) في وسائل التواصل الاجتماعي إنستغرام } \\
& \text { صور مضحكة من خمسة معان ، هي: الفرح والحزن والغضب والفجأة والحياد. } \\
& \text { الكلمات المفتاحية : ميمي ، اللغة العربية الفصحى ، الوحدة اللغوية ، سميوطيقا . }
\end{aligned}
$$

\section{PENDAHULUAN}

Media sosial muncul sebagai media daring berbasis internet yang memudahkan penggunanya untuk berbagi, berpartisipasi, dan menciptakan konten berupa blog, wiki, forum, jejaring sosial, dan ruang dunia virtual yang didukung oleh teknologi multimedia yang semakin canggih (Tim Pusat Humas Kementerian Perdagangan RI, 2014:25). Selain itu, pengguna media sosial dapat mengedit, menyebarkan, dan memodifikasi baik, tulisan, gambar, video, grafis, maupun berbagai bentuk konten yang lain melalui media sosial.

Berdasarkan hal tersebut, internet, media sosial, dan teknologi multimedia menjadi kesatuan yang sulit dipisahkan dan mendorong pada hal-hal baru (Tim Pusat Humas Kementerian Perdagangan RI, 2014:25). Salah satunya adalah fenomena internet meme. Meme merupakan istilah yang diciptakan oleh Richard Dawkins pada tahun 1976 untuk menjelaskan unit kecil budaya yang menyebar dari satu orang ke orang lainnya dengan menyalin atau meniru. Dalam perkembangannya, istilah meme digunakan pengguna internet pada umumnya untuk menggambarkan penyebaran hal-hal seperti lelucon, rumor, video, dan situs dari satu orang ke orang yang lain melalui internet (Shifman, 2014:2).

Penyebaran meme tidak hanya terbatas pada penguna internet dalam suatu negara. Akan tetapi, meme menyebar dari pengguna internet suatu negara ke pengguna internet negara lainnya yang aktif menggunakan media sosial. Begitu pula di negara-negara Arab, sebagaimana yang dinyatakan oleh Arab Social Media Influencers Summit pada tahun 2015 (2015:3) $12 \%$ pengguna media sosial di negara-negara Arab menggunakan media sosial sebagai media untuk memperoleh informasi, menonton video, mendengarkan musik, dan berbagi foto. Penyebaran meme di negara-negara Arab dapat ditemukan seperti di Facebook, Instagram, Website dan sebagainya.

Davinson (2012:127) menyatakan salah satu struktur internet meme yang umum digunakan adalah image macro yang terdiri dari gambar dan teks. Berdasarkan hal tersebut bentuk meme berbahasa Arab dapat diklasifikasikan berdasarkan aspek lingual dan aspek visual. Bentuk berdasarkan aspek lingual diklasifikasikan berdasarkan satuan lingual yang terdapat di meme. Adapun bentuk berdasarkan aspek visual diklasifikasikan berdasarkan tipologi tanda yang terdapat di meme.

Rage comics adalah salah satu jenis genre meme yang menampilkan satu set karakter ekspresif (rage face), masingmasing terkait dengan perilaku dan emosi yang khas (Shifman, 2014:113). Ekspresi wajah dapat dibagi menjadi komponenkomponen karakteristik posisi alis, bentuk mata, bentuk mulut, ukuran lubang hidung, dan lainnya dalam pelbagai kombinasi untuk menentukan bentuk dan makna dari ekspresi bersangkutan 
(Danesi, 2011:58). Dengan demikian, tanda visual ekspresi wajah yang terdapat pada rage face rage comics dapat mengungkap makna rage face rage comics.

Penelitian ini mengkaji bentuk dan makna meme berbahasa Arab dalam media sosial Instagram Shuwarun Mudhchikatun karena bentuk meme berbahasa Arab dapat diklasifikasikan berdasarkan aspek lingual dan aspek visual, serta tanda visual ekspresi wajah yang terdapat pada rage face meme rage comics dapat mengungkap makna rage face meme rage comics.

Selain itu, Instagram merupakan media sosial paling populer yang digunakan untuk mengirim foto (Landsverk, 2014:2). Instagram juga merupakan media sosial keempat yang sering digunakan pengguna internet di negara-negara Arab (Arab Social Media Influencers Summit, 2015:4). Adapun sumber data adalah Shuwarun Mudhchikatun yang merupakan akun Instagram yang aktif mengunggah meme berbahasa Arab di Instagram sejak tahun 2014. Selain itu, akun tersebut memiliki pengikut lebih dari 2 juta pengikut $(\mathrm{NN}$, TT,

www.instagram.com/9owar_md7eka/.

Adapun permasalahan yang akan dikaji pada penelitian ini yaitu berkaitan dengan bentuk meme berbahasa Arab dalam media sosial Instagram Shuwarun Mudhchikatun dan makna rage face dalam media sosial Instagram Shuwarun Mudhchikatun.

Teori yang digunakan pada penelitian ini adalah teori Sintaksis yang terdiri dari teori kata Ni'mah (1988), teori frase Ryding (2014), teori klausa Asrori (2005), dan teori kalimat Asrori (2005). $\mathrm{Ni}^{\text {'mah }}$ (1988:17) membagi kata dalam bahasa Arab dibagi menjadi tiga, yaitu ism, fi'l, dan charf . Ryding (2014:119123) membagi frase bahasa Arab berdasarkan strukturnya menjadi dua, yaitu (1) agreement-based phrase structure yang terdiri atas frase nomina, frase nomina dalam aposisi, frase nomina dalam koordinasi, frase nomina + ajektiva, dan frase determinator bahasa Arab, (2) government-based phrase structure yang terdiri atas frase preposisional dan frase konstruksi genetif. Asrori (2005:80) membagi klausa dalam bahasa Arab berdasarkan jenis kata atau frase yang menjadi predikat menjadi tiga, yaitu klausa verbal (jumlah fi'liyyah), klausa nomina (jumlah ismiyyah), dan klausa preposisional (syibhul-jumlah). Asrori (2005:101) membagi kalimat dalam bahasa Arab berdasarkan jumlah dan jenis klausa menjadi tiga, yaitu kalimat tunggal (kalām basìth), kalimat majemuk bersusun (kalām tarkībì), dan kalimat majemuk setara (kalām murakkab).

Selain itu, juga teori semiotika, yaitu tipologi tanda Peirce (1986) dan segitiga semiotika Peirce (1986). Peirce dalam Budiman (2011:19-22) membagi tipe-tipe tanda dapat dibedakan berdasarkan relasi di antara representamen dan objeknya menjadi tiga, yaitu ikon (icon), indeks (index), simbol (symbol). Peirce dalam (Budiman, 2011:17) menyatakan sebuah tanda atau representamen memiliki relasi triadik langsung dengan interpretan dan objeknya dalam segitiga semiotika.

Teori lain yang digunakan yaitu teori internet meme Shifman (2014), rage comics (Sav, 2011, http://knowyourmeme.com/memes/ragecomics) dan ekspresi wajah Tekalp dan Jörn (2000). Telkap dan Jörn (2000:392) mendeskripsikan enam pokok ekspresi wajah, yaitu senang, sedih, marah, takut, jijik, terkejut, dan netral.

\section{METODOLOGI PENELITIAN}

Penelitian ini melalui tiga tahapan, yaitu penyediaan data, analisis data dan penyajian hasil analisis data. Penyediaan data penelitian ini menggunakan metode simak, yaitu metode yang dilakukan dengan menyimak penggunaan bahasa (Sudaryanto, 2015:201). Teknik dasar dari metode ini adalah teknik sadap, yaitu menyadap penggunaan bahasa seseorang 
atau beberapa orang baik berbentuk lisan maupun tulisan (Kesuma, 2007:43). Selanjutnya, teknik lanjutan dari metode ini adalah teknik simak bebas libat cakap dan teknik catat.

Analisis data penelitian ini menggunakan metode agih. Metode agih adalah metode yang alat penentunya terletak di bagian dari bahasa yang bersangkutan (Sudaryanto, 2015:18). Teknik dasar metode ini berupa teknik bagi unsur langsung (BUL). Teknik ini dilakukan dengan membagi satuan lingual menjadi beberapa bagian yang dipandang sebagai bagian dari satuan lingual yang akan diteliti (Sudaryanto, 2015:38). Selain itu, penelitian ini juga menggunakan metode analisis kualitatif taksonomi, yaitu metode analisis terhadap keseluruhan data yang terkumpul berdasarkan domain yang telah ditetapkan (Sugiyono, 2014:110). Adapun penyajian hasil analisis data menggunakan metode informal. Metode informal adalah penyajian hasil analisis data dengan menggunakan kata-kata biasa (Kesuma, 2007:71).

\section{PEMBAHASAN}

\section{Bentuk Meme Berbahasa Arab dalam Media Sosial Instagram Shuwarun Mudhchikatun \\ Bentuk meme berbahasa Arab} dalam media sosial Instagram Shuwarun Mudhchikatun diklasifikasikan berdasarkan aspek lingual dan aspek visual. Bentuk berdasarkan aspek lingual diklasifikasikan berdasarkan satuan lingual yang terdapat di meme. Adapun bentuk berdasarkan aspek visual diklasifikasikan berdasarkan tipologi tanda yang terdapat di meme.

\section{a. Bentuk Meme Berbahasa Arab Berdasarkan Aspek Lingual}

1) Kata

Bentuk meme berbahasa Arab yang aspek lingualnya berbentuk kata dalam media sosial Instagram Shuwarun Mudhchikatun ditemukan sebanyak lima data meme. Berikut ini disajikan data meme yang aspek lingualnya berbentuk kata.

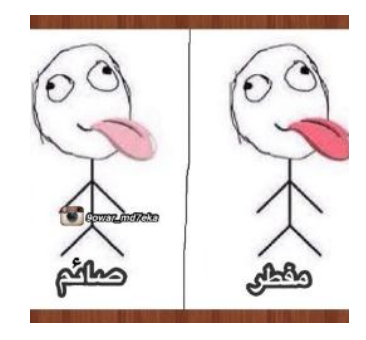

مفطر، صائم

/Mufthirun/, /shā'imun/

'Orang yang tidak berpuasa', 'orang yang berpuasa' (@9owar_md7eka, Juni, 2015)

\begin{tabular}{|c|c|c|}
\hline م & م & $\begin{array}{c}\text { Satuan } \\
\text { lingual }\end{array}$ \\
\hline shā'imun & mufthirun & Transliterasi \\
\hline $\begin{array}{c}\text { orang } \\
\text { yang } \\
\text { berpuasa }\end{array}$ & $\begin{array}{c}\text { orang tidak } \\
\text { berpuasa }\end{array}$ & Terjemah \\
\hline $\mathrm{N}$ & $\mathrm{N}$ & Kategori \\
\hline
\end{tabular}

Contoh di atas terdiri atas dua satuan lingual, yaitu /shāimun/ 'orang yang berpuasa' dan /mufthirun/ 'orang tidak berpuasa'. Kedua satuan lingual tersebut termasuk ke dalam ism karena menerima penanda ism berupa tanwin Selain itu, keduanya menunjukkan kepada unsur makna manusia. Kedua ism di atas juga berdiri sendiri tanpa membentuk satuan lingual yang lebih besar. Dengan demikian, bentuk satuan lingual dari contoh di atas adalah kata.

Selain itu, ditemukan pula bentuk meme berbahasa Arab yang aspek lingualnya terdiri atas gabungan kata dengan satuan lain, yaitu kata dengan frase.

\section{2) Frase}

Bentuk meme berbahasa Arab yang aspek lingualnya berbentuk frase dalam media sosial Instagram Shuwarun Mudhchikatun ditemukan sebanyak dua puluh tiga data meme. Berikut ini disajikan data meme yang aspek lingualnya berbentuk frase. 


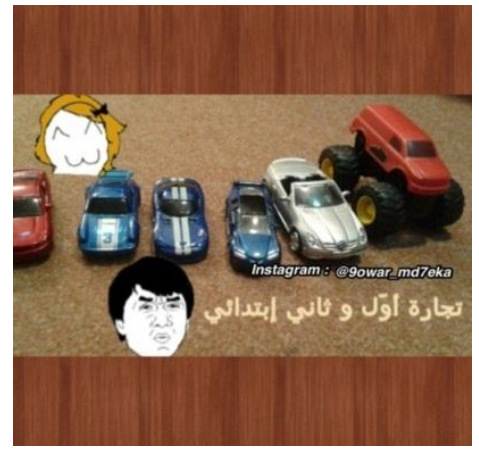

تجارة أول و ثاني إبتدائي

/Tijāratu awwalin wa tsāniyi ibtidā'iyin/

'Perdagangan siswa kelas satu dan kelas dua sekolah dasar' (@9owar_md7eka, Juni, 2015)

\begin{tabular}{|c|c|c|c|c|c|}
\hline إبندئي & ثاني & g & أول & 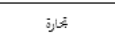 & $\begin{array}{l}\text { Satuan } \\
\text { lingual }\end{array}$ \\
\hline ibtidā'iyin & tsāniȳi & wa & awwalin & tijāratu & Transliterasi \\
\hline sekolah & kedua & dan & pertama & perdagangan & Terjemah \\
\hline Adi & $\mathrm{N}$ & Konj & $\mathrm{N}$ & $\mathrm{N}$ & \multirow{4}{*}{ Kategori } \\
\hline & & & MI & $\mathrm{M}$ & \\
\hline & $\mathrm{N}$ & Konj & $\mathrm{N}$ & & \\
\hline Adj & $\mathrm{N}$ & & & & \\
\hline
\end{tabular}

Contoh di atas terdiri atas tiga bentuk satuan lingual. Pertama, satuan lingual yang terdiri atas kata /tijāratu/ 'perdagangan' sebagai mudhäf dan kata /awwalin/ 'pertama' sebagai mudhäf ilaih. Satuan lingual tersebut termasuk ke dalam frase konstruksi genetif (idhāfah). Kedua, satuan lingual yang terdiri atas kata /awwalin/ 'pertama' dan kata /tsāniyi// 'kedua' sebagai nomina yang berkoordinasi dan kata / wal 'dan' sebagai konjungsi yang menghubungkan kata /awwalin/ dan kata /tsāniyī/. Satuan lingual tersebut termasuk ke dalam frase nomina dalam koordinasi. Ketiga, satuan lingual yang terdiri atas kata /tsāniȳi/ 'kedua' sebagai nomina dan kata /ibtidā'iyin/ 'sekolah dasar' sebagai ajektiva yang mengikuti nomina. Satuan lingual tersebut termasuk ke dalam frase nomina berstuktur nomina + ajektiva. Selain itu, pada contoh di atas tidak terdapat satuan lingual yang berfungsi sebagai predikat. Berdasarkan hal tersebut contoh di atas termasuk ke dalam satuan lingual frase karena terdiri atas frase konstruksi genetif (idhăfah), frase nomina dalam koordinasi, frase nomina berstruktur nomina + ajektiva dan tidak bersifat predikatif.

Selain itu, ditemukan pula bentuk meme berbahasa Arab yang aspek lingualnya terdiri atas gabungan frase dengan satuan lingual lain, yaitu frase dengan kata, frase dengan klausa dan frase dengan kalimat.

3) Klausa

Bentuk meme berbahasa Arab yang aspek lingualnya berbentuk klausa dalam media sosial Instagram Shuwarun Mudhchikatun ditemukan sebanyak tiga data meme. Berikut ini disajikan data meme yang aspek lingualnya berbentuk klausa.
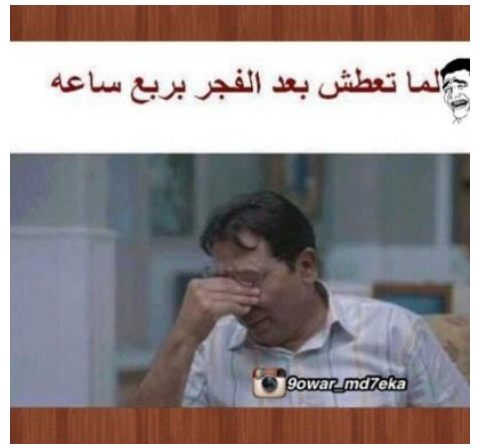

لما تعطش بعد الفجر بربع ساعه

/Lammā ta'thasyu ba'dalfajri birub'i sā'ah/

'Ketika kamu merasa haus setelah subuh seperempat jam’ (@9owar_md7eka, Juli, 2015) 


\begin{tabular}{|c|c|c|c|c|}
\hline 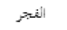 & بعد & تعطش & th & Satuan lingual \\
\hline al-fajri & ba'da & ta'thasyu & lamma & Transliterasi \\
\hline subuh & setelah & kamu merasa haus & ketika & Terjemah \\
\hline $\mathrm{N}$ & Adv & V imperf pron 2nd & Par & Kategori \\
\hline Ket. & aktu & $\mathrm{P}+\mathrm{S}$ & & Fungsi \\
\hline
\end{tabular}

\begin{tabular}{|c|c|c|c|}
\hline sel & cj & - & Satuan lingual \\
\hline sā'ah & rub'i & $\mathrm{Bi}$ & Transliterasi \\
\hline jam & seperempat & dengan & Terjemah \\
\hline $\mathrm{N}$ & $\mathrm{N}$ & Par & Kategori \\
\hline \multicolumn{3}{|c|}{ Ket. Waktu } & Fungsi \\
\hline
\end{tabular}

Contoh di atas diawali dengan kata /lamma/ 'ketika' yang menempati kategori partikel, lalu kata /ta'thasyu/ 'kamu merasa haus' yang menempati fungsi predikat ( $\left.f i^{\circ}\right)$ dan subjek ( $\left.f a^{\prime} i\right)$. Setelah itu, diikuti frase /ba'dal-fajri birub'i sā'ah/ 'setelah subuh seperempat jam' yang menempati fungsi keterangan waktu. Dengan demikian, bentuk satuan lingual dari contoh di atas adalah klausa karena termasuk ke dalam klausa verbal yang predikatnya berupa kata verba ( $\left.f i^{\circ}\right)$.

4) Kalimat

Bentuk meme berbahasa Arab yang aspek lingualnya berbentuk kalimat dalam media sosial Instagram Shuwarun Mudhchikatun ditemukan sebanyak enam belas data meme. Berikut ini disajikan data meme yang aspek lingualnya berbentuk kalimat.

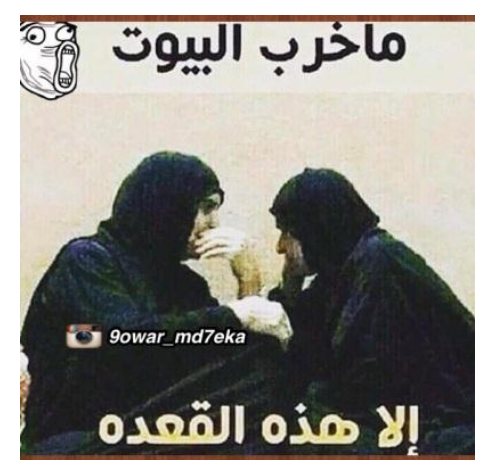

$$
\text { ماخرب البيوت إلا هذه القعده }
$$

/Mā kharabal-buyūta illa hadzihil-qi'dah/

'Tidak ada yang menghancurkan rumah tangga kecuali duduk seperti ini' (@9owar_md7eka, Juli, 2015)

\begin{tabular}{|c|c|c|c|c|c|c|}
\hline القعده & حذه & إ & البيوت & خرب & 6 & $\begin{array}{l}\text { Satuan } \\
\text { lingual }\end{array}$ \\
\hline $\begin{array}{l}\text { al- } \\
\text { gitdah }\end{array}$ & hadzihi & illa & al-buyūta & kharaba & mā & Transliterasi \\
\hline $\begin{array}{l}\text { tempat } \\
\text { duduk }\end{array}$ & ini & kecuali & $\begin{array}{l}\text { rumah- } \\
\text { rumah }\end{array}$ & $\begin{array}{l}\text { dia } \\
\text { menghancur } \\
\text { kan }\end{array}$ & tidak & Terjemah \\
\hline $\mathrm{N}$ & $\mathrm{N}$ & Par & $\mathrm{N}$ & $\begin{array}{l}\text { V perf pron } \\
\text { 3rd }\end{array}$ & Par & Kategori \\
\hline & & & $\mathrm{O}$ & $\mathrm{P}$ & & Fun \\
\hline
\end{tabular}

Contoh di atas diawali dengan satuan lingual kata /ma/ 'tidak' yang menempati kategori partikel, lalu kata /kharaba/ 'dia menghancurkan' yang menempati fungsi predikat (fi'). Selanjutnya, kata /al-buyūta/ 'rumahrumah' menempati fungsi objek ( $m a f^{*} \bar{u} l$ bih) dan frase /hadzihil-qi'dah/ 'duduk seperti ini' menempati fungsi subjek (fä $i$ 'i). Berdasarkan hal tersebut, satuan lingual di atas hanya terdiri dari satu klausa. Dengan demikian, bentuk satuan lingual dari contoh di atas adalah kalimat karena termasuk ke dalam kalimat tunggal yang terdiri atas satu klausa berupa klausa bebas.

\section{b. Bentuk Meme Berbahasa Arab Berdasarkan Aspek Visual}

\section{1) Ikon}

Bentuk meme berbahasa Arab yang aspek visualnya berbentuk ikon dalam media sosial Instagram Shuwarun Mudhchikatun ditemukan sebanyak enam belas data meme. Berikut ini disajikan data meme yang aspek visualnya berbentuk ikon.

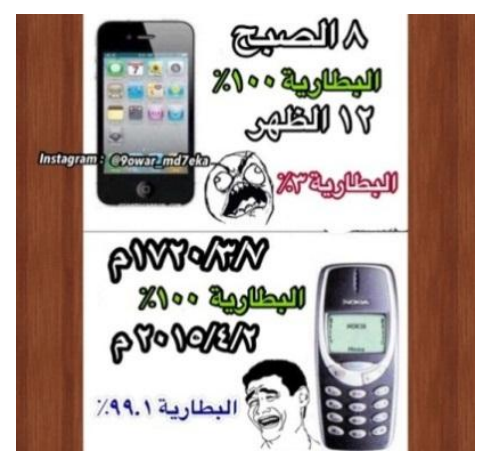




\begin{tabular}{|l|r|}
\hline $\begin{array}{l}\text { Tipologi } \\
\text { Tanda }\end{array}$ & Tanda Visual \\
\hline Ikon & \\
\hline Ikon & \\
\hline Ikon & \\
\hline Ikon & \\
\hline
\end{tabular}

Contoh di atas dari aspek visualnya terdiri atas empat tanda visual, yaitu tanda smartphone, tanda rage face Rage Guy (FFFFFFUUUUUU), tanda rage face Yao Ming/Bitch Please, dan tanda telepon seluler Nokia. Tanda smartphone merupakan tanda yang digunakan sebagai penyerupaan smartphone yang kuantitas baterainya pada jam delapan pagi $100 \%$ dan pada jam dua belas siang yang kuantitas baterainya $3 \%$. Tanda rage face Rage Guy (FFFFFFUUUUUU) merupakan tanda yang digunakan sebagai penyerupaan ekspresi marah karena cepat berkurangnya persentase baterai smartphone.

Adapun tanda telepon seluler Nokia merupakan tanda yang digunakan sebagai penyerupaan telepon seluler Nokia yang pada tanggal 30 Juli 1720 kuantitas baterainya $100 \%$ dan pada 4 Februari 2015 yang kuantitas baterainya 99,1\%. Tanda rage face Yao Ming/Bitch Please merupakan tanda yang digunakan sebagai penyerupaan ekspresi senang atas sedikitnya persentase baterai telepon seluler Nokia yang berkurang selama kurun waktu tersebut. Berdasarkan hal tersebut, tanda smartphone, tanda rage face Rage Guy (FFFFFFUUUUUU), tanda rage face Yao Ming/Bitch Please, dan tanda telepon seluler Nokia termasuk ke dalam tipologi tanda ikon yang mengandung kemiripan rupa. Dengan demikian, bentuk berdasarkan aspek visual contoh di atas adalah ikon.

2) Ikon dan Indeks

Bentuk meme berbahasa Arab yang aspek visualnya berbentuk ikon dan indeks dalam media sosial Instagram Shuwarun Mudhchikatun ditemukan sebanyak empat data meme. Berikut ini disajikan data meme yang aspek visualnya berbentuk ikon dan indeks.

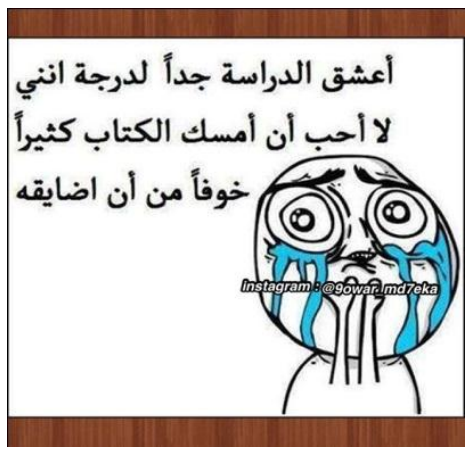

(@9owar_md7eka, Juli, 2015)

\begin{tabular}{|l|l|}
\hline $\begin{array}{l}\text { Tipologi } \\
\text { Tanda }\end{array}$ & $\begin{array}{l}\text { Tanda } \\
\text { Visual }\end{array}$ \\
\hline Ikon & \\
\hline Indeks & \\
\hline
\end{tabular}

Contoh di atas dari aspek visualnya terdiri atas dua tanda visual, yaitu tanda rage face Cuteness Overload dan tanda air mata. Rage face Cuteness Overload merupakan tanda yang digunakan sebagai penyerupaan 
penutur kalimat /a'syaqu'd-dirāsata jiddan lidarajati annani là uchibbu an umsikal-kitāba katsīran khaufan min an udhāyiqahu/ yang mencintai belajar tapi jarang membuka buku karena takut menyusahkannya. Tanda air mata merupakan merupakan tanda yang memiliki keterkaitan dengan menangis karena air mata muncul disebabkan oleh menangis. Berdasarkan hal tersebut, tanda rage face Cuteness Overload termasuk ke dalam tipologi tanda ikon yang mengandung kemiripan rupa. Adapun tanda air mata termasuk ke dalam tipologi tanda indeks yang memiliki hubungan sebab akibat. Dengan demikian, bentuk berdasarkan aspek visual data meme di atas adalah ikon dan indeks.

\section{3) Ikon dan Simbol}

Bentuk meme berbahasa Arab yang aspek visualnya berbentuk ikon dan simbol dalam Media Sosial Instagram Shuwarun Mudhchikatun ditemukan sebanyak dua puluh empat data meme. Berikut ini disajikan data meme yang aspek visualnya berbentuk ikon dan simbol.

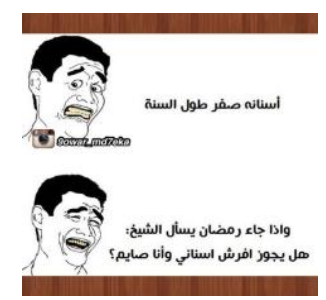

(@9owar_md7eka, Juni, 2015)

\begin{tabular}{|l|l|}
\hline $\begin{array}{l}\text { Tipologi } \\
\text { Tanda }\end{array}$ & $\begin{array}{l}\text { Tanda } \\
\text { Visual }\end{array}$ \\
\hline Ikon & \\
\hline & \\
Ikon & \\
&
\end{tabular}

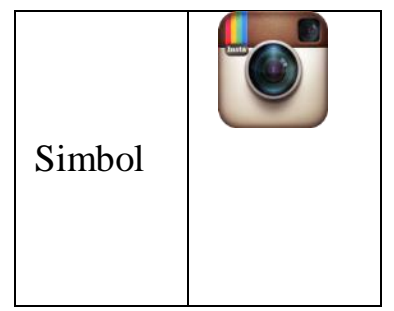

Contoh di atas dari aspek visualnya terdiri atas tiga tanda visual, yaitu tanda rage face Yao Ming/Bitch Please dengan gigi berwarna kuning, tanda rage face Yao Ming/Bitch Please dengan gigi berwarna putih dan tanda kamera. Rage face Yao Ming/Bitch Please dengan gigi berwarna kuning merupakan tanda yang digunakan sebagai penyerupaan orang yang disebutkan dalam klausa /asnānuhū shufrun thulas-sanah/ yang memiliki gigi kuning sepanjang tahun. Rage face Yao Ming/Bitch Please dengan gigi berwarna putih merupakan tanda yang digunakan sebagai penyerupaan ekspresi senang atas kalimat /wa idzā jà' a ramadhāna yas'alusy-syaikhu : hal yajūzu afrusyu asnānì wa anā shāimun?/ yang berisi hal lucu. Adapun tanda kamera merupakan tanda yang secara konvensional dikenal sebagai logo dari media sosial Instagram oleh orang yang mengetahui tentang media sosial Instagram www.instagram-brand.com.

Berdasarkan hal tersebut, tanda rage face Yao Ming/Bitch Please dengan gigi berwarna kuning dan tanda rage face Yao Ming/Bitch Please dengan gigi berwarna putih termasuk ke dalam tipologi tanda ikon yang mengandung kemiripan rupa. Adapun tanda kamera termasuk ke dalam tipologi tanda simbol. Dengan demikian, bentuk berdasarkan aspek visual data meme di atas adalah ikon dan simbol.

4) Ikon, Indeks, dan Simbol

Bentuk meme berbahasa Arab yang aspek visualnya berbentuk ikon, indeks dan simbol dalam media sosial Instagram Shuwarun Mudhchikatun 
ditemukan sebanyak tiga data meme. Berikut ini disajikan data meme yang aspek visualnya berbentuk ikon, indeks dan simbol.

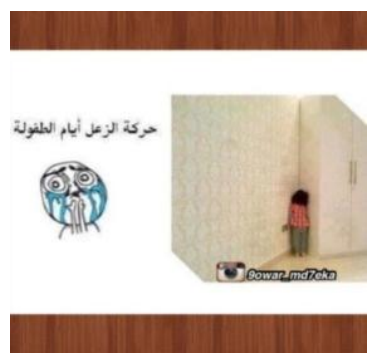

(@9owar_md7eka, Juni, 2015)

\begin{tabular}{|l|l|}
\hline $\begin{array}{l}\text { Tipologi } \\
\text { Tanda }\end{array}$ & Tanda Visual \\
\hline Ikon & \\
\hline Ikon & \\
\hline Ikon & \\
\hline Indeks & \\
\hline Simbol & \\
\hline
\end{tabular}

Contoh di atas dari aspek visualnya terdiri atas tanda anak kecil, tanda tembok, tanda rage face Cuteness Overload, tanda air mata, dan tanda kamera. Tanda anak kecil merupakan tanda yang digunakan sebagai penyerupaan anak kecil yang disebutkan dalam frase /charakatu'zza'ali ayyāma'th-thufūlah/ yang sedang marah dengan menghadap tembok. Tanda tembok merupakan penyerupaaan dari tembok. Tanda rage face Cuteness Overload merupakan tanda yang menujukkan ekspresi atas bentuk kemarahan pada masa anakanak. Tanda air mata merupakan merupakan tanda yang memiliki keterkaitan dengan menangis karena air mata muncul disebabkan oleh menangis. Adapun tanda kamera merupakan tanda yang secara konvensional dikenal sebagai logo dari media sosial Instagram oleh orang yang mengetahui tentang media sosial Instagram

brand.com.

www.instagram-

Berdasarkan hal tersebut, tanda anak kecil, tanda tembok, tanda rage face Cuteness Overload termasuk ke dalam tipologi tanda ikon yang mengandung kemiripan rupa. Tanda air mata termasuk ke dalam tipologi tanda indeks yang memiliki hubungan sebab akibat. Adapun tanda kamera termasuk ke dalam tipologi tanda simbol. Dengan demikian, bentuk berdasarkan aspek visual data meme di atas adalah ikon dan simbol.

\section{Makna Rage Face dalam Media Sosial Instagram Shuwarun Mudhchikatun}

Makna rage face yang ditemukan dalam media sosial Instagram Shuwarun Mudhchikatun mengacu pada delapan rage face yang terdapat pada www.knowyourmeme.com. Selain itu, makna rage face mengacu pada karakter ekspresif lain yang ditemukan sejumlah dua puluh dua rage face yang terdapat www.memes.at Berdasarkan hal tersebut makna rage face dalam media sosial Instagram Shuwarun Mudhchikatun dapat diklasifikasikan sebagai berikut.

a. Senang

Rage face dalam media sosial Instagram Shuwarun Mudhchikatun yang memiliki makna senang ditemukan sebanyak lima belas rage face. Berikut ini disajikan data rage face yang memiliki makna senang. 

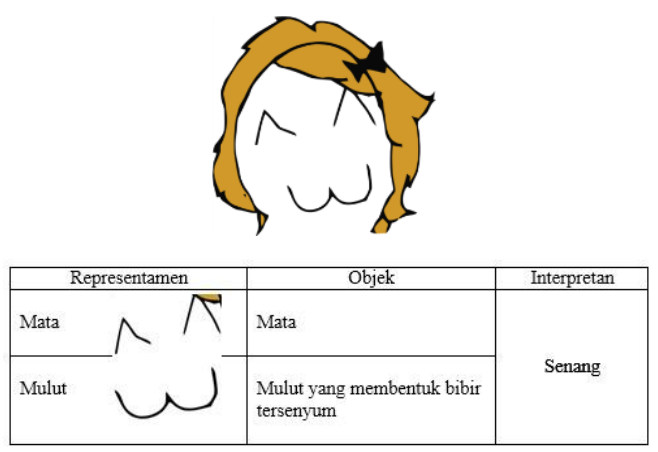

Contoh di atas merupakan rage face Derpina yang terdiri atas representamen mata dan mulut. Representamen mata rage face Derpina memiliki bentuk seperti huruf $\mathrm{V}$ terbalik. Representamen mata tersebut mengacu kepada objek bentuk mata. Adapun representamen mulut rage face Derpina memiliki bentuk dua lengkungan yang mengarah ke atas. Representamen mulut tersebut mengacu kepada objek bentuk mulut yang ujung sudut-sudutnya tertarik ke atas untuk membentuk senyuman. Berdasarkan hal tersebut interpretan atau makna rage face Derpina adalah ekspresi senang.

\section{b. Sedih}

Rage face dalam media sosial Instagram Shuwarun Mudhchikatun yang memiliki makna sedih ditemukan sebanyak empat rage face. Berikut ini disajikan data rage face yang memiliki makna sedih.
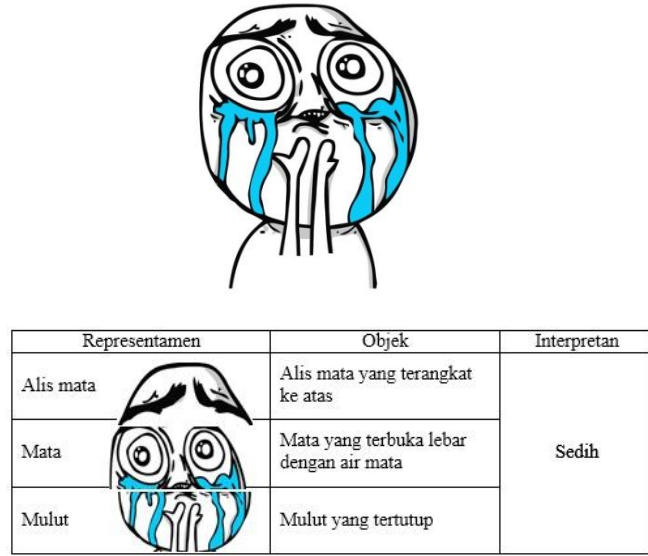

Contoh di atas merupakan rage face Cuteness Overload yang terdiri atas representamen alis mata, mata, dan mulut. Representamen alis mata rage face Cuteness Overload memiliki bentuk alis yang bagian dalam terangkat ke atas. Representamen alis mata tersebut mengacu kepada objek bentuk alis mata yang bagian dalam terangkat ke atas. Representamen mata rage face Cuteness Overload memiliki bentuk mata yang terbuka lebar dengan air mata yang mengalir. Representamen mata tersebut mengacu kepada objek bentuk mata yang terbuka lebar dengan air mata yang mengalir. Representamen mulut rage face Cuteness Overload memiliki bentuk mulut yang tertutup rapat. Representamen mulut tersebut mengacu kepada objek bentuk mulut yang tertutup rapat. Berdasarkan hal tersebut interpretan atau makna rage face Cuteness Overload adalah ekspresi sedih.

c. Marah

Rage face dalam media sosial Instagram Shuwarun Mudhchikatun yang memiliki makna marah ditemukan sebanyak empat rage face. Berikut ini disajikan data rage face yang memiliki makna marah.
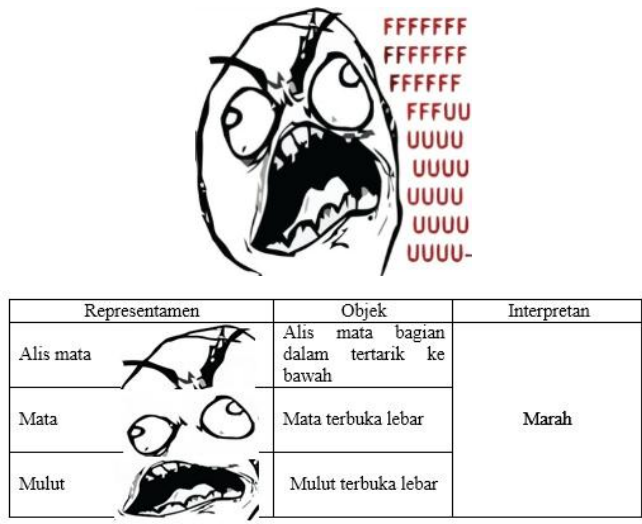

Contoh di atas merupakan rage face Rage Guy (FFFFFFUUUUUU) yang terdiri atas representamen alis mata, mata, dan mulut. Representamen alis mata rage face Rage Guy (FFFFFFUUUUUU) memiliki bentuk 
alis mata bagian dalam tertarik ke bawah. Representamen alis mata tersebut mengacu kepada objek bentuk alis mata yang bagian dalamnya tertarik ke bawah. Representamen mata rage face Rage Guy (FFFFFFUUUUUU) memiliki bentuk mata yang terbuka lebar. Representamen mata tersebut mengacu kepada objek bentuk mata yang terbuka lebar. Representamen mulut rage face Rage Guy (FFFFFFUUUUUU) memiliki bentuk mulut yang terbuka lebar. Representamen mulut tersebut mengacu kepada objek bentuk mulut yang terbuka lebar seperti orang berteriak. Berdasarkan hal tersebut interpretan atau makna rage face Rage Guy (FFFFFFUUUUUU) adalah ekspresi marah.

\section{d. Terkejut}

Rage face dalam media sosial Instagram Shuwarun Mudhchikatun yang memiliki makna terkejut ditemukan sebanyak empat rage face. Berikut ini disajikan data rage face yang memiliki makna terkejut.
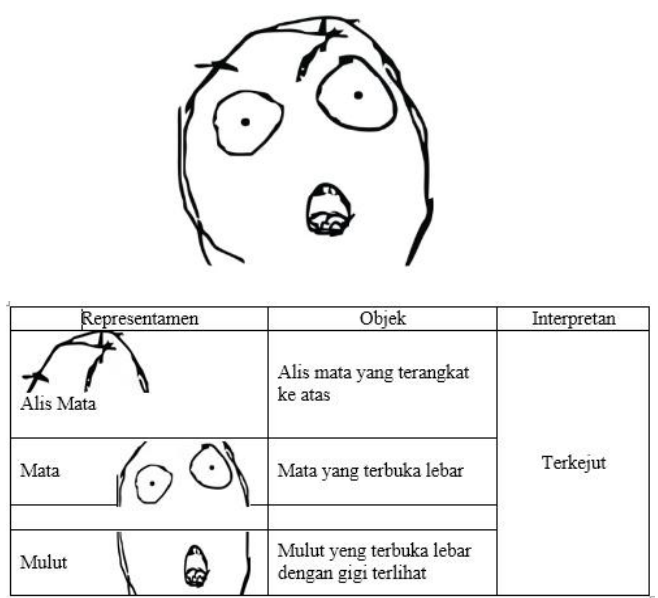

Contoh di atas merupakan rage face Suprised Wide Open yang terdiri atas representamen alis mata, mata, dan mulut. Representamen alis mata rage face Suprised Wide Open memiliki bentuk alis mata yang terangkat ke atas. Representamen alis mata tersebut mengacu kepada objek bentuk alis mata yang terangkat ke atas. Representamen mata rage face Suprised Wide Open memiliki bentuk mata yang terbuka lebar. Representamen mata tersebut mengacu kepada objek bentuk mata yang terbuka lebar. Representamen mulut rage face Suprised Wide Open memiliki bentuk mulut yang terbuka lebar. Representamen mulut tersebut mengacu kepada objek bentuk mulut yang terbuka lebar dengan terlihar gigi karena rahang terbuka. Berdasarkan hal tersebut interpretan atau makna rage face Suprised Wide Open adalah ekspresi terkejut.

e. Netral

Rage face dalam media sosial Instagram Shuwarun Mudhchikatun yang memiliki makna netral ditemukan sebanyak tiga rage face. Berikut ini disajikan data rage face yang memiliki makna terkejut.
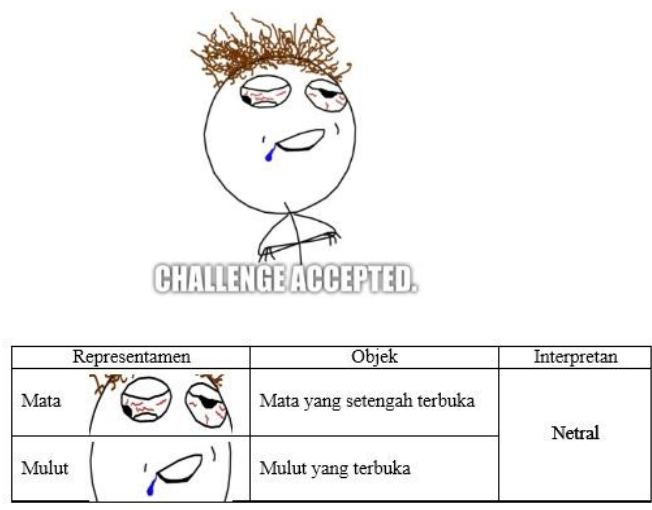

Contoh di atas merupakan rage face Challange Accepted Drunk yang terdiri atas representamen mata dan mulut. Representamen mata rage face Challange Accepted Drunk memiliki bentuk mata yang setengah terbuka dengan terdapat garis merah. Representamen mata tersebut mengacu kepada objek bentuk mata yang setengah terbuka karena lemas. Representamen mulut rage face Challange Accepted Drunk memiliki bentuk mulut yang terbuka. Representamen mulut tersebut mengacu kepada objek bentuk mulut yang terbuka. Berdasarkan hal tersebut interpretan atau makna rage face 
Challange Accepted Drunk adalah ekspresi netral.

\section{KESIMPULAN}

Berdasarkan hasil penelitian Meme Berbahasa Arab dalam Media Sosial Instagram Shuwarun Mudhchikatun yang telah dilakukan, simpulan yang diperoleh adalah bentuk meme berbahasa Arab dalam media sosial Instagram Shuwarun Mudhchikatun terdiri atas dua bentuk, yaitu bentuk berdasarkan aspek lingual dan bentuk berdasarkan aspek visual. Bentuk meme berbahasa Arab berdasarkan aspek lingual ditemukan dalam bentuk satuan lingual kata, frase, klausa, dan kalimat. Selain itu, juga ditemukan gabungan beberapa satuan lingual yaitu, gabungan satuan lingual kata dengan frase, frase dengan kata, frase dengan klausa, dan frase dengan kalimat. Bentuk kata ditemukan sebanyak lima data. Bentuk frase ditemukan sebanyak dua puluh tiga data. Bentuk klausa ditemukan sebanyak tiga data. Bentuk kalimat ditemukan sebanyak enam belas data. Bentuk meme berbahasa Arab berdasarkan aspek visual ditemukan dalam bentuk ikon, ikon dan indeks, ikon dan simbol, serta ikon, indeks dan simbol. Adapun makna rage face dalam media sosial Instagram Shuwarun Mudhchikatun yang ditemukan terdiri atas lima makna, yaitu makna senang, sedih, marah, terkejut dan netral.

\section{DAFTAR PUSTAKA}

Arab Social Media Influencers Summits. 2015. Arab Social Media Report. Dubai.

Asrori, Imam. 2004. Sintaksis Bahasa Arab Frasa-Klausa-Kalimat. Malang: Misykat.

Budiman, Kris. 2011. Semiotika Visual: Konsep, Isu, dan Problem Ikonitas. Yogyakarta: Jalasutra.

Danesi, Marcel. 2011. Pesan, Tanda, dan Makna: Buku Teks Dasar Mengenai Semiotika dan Teori Komunikasi.
Diterjemahkan oleh: Evi Setyarini dan Lusi Lian Piantari. Yogyakarta: Jalasutra.

Davinson, Patrick. 2012. The Language of Internet Memes. Mandiberg, Michael (ed). The Sosial Media Reader. New York: New York University.

Dhianari, Ni Made. 2011. Ragam Bahasa Kaskus. Tesis. Denpasar: Universitas Udayana.

Istiyani, Tri. 2013. Makna dan Fungsi dalam Novel (Neukdaeeui Yuhok I) Karya Gwiyoni: Kajian Semiotika Pierce. Skripsi. Yogyakarta: Fakultas Ilmu Budaya Universitas Gadjah Mada.

Kesuma, Tri Mastoyo Jati. 2007. Pengantar (Metode) Penelitian Bahasa. Yogyakarta: Carasvatibooks.

Landsverk, Kjell Halvor. 2014. The Instagram Handbook 2014 Edition. London: Prime Head Limited.

Luvytasari, Hanny. 2015. Meme Instagram Dagelan Kajian Sosiolinguistik. Skripsi. Yogyakarta: Fakultas Ilmu Budaya Universitas Gadjah Mada.

Ni'mah, Fuad. 1988. Mulakhkhash Qawā'idu Al-Lughati Al'Arabiyyah. Beirut: Dāru AtsTsaqafah Al-Islāmiyah.

Ryding, Karin C. 2014. Arabic A Linguistic Introduction. New York: Cambridge University Press.

Sayani, Made Nunik. 2013. Semiotic Analysis of Memes in 9gag.com. Humanis. Vol. V. No. 1, hlm. 1-10.

Shifman, Limor. 2014. Meme in Digital Culture. Cambridge: MIT Press.

Sudaryanto. 2015. Metode dan Aneka Teknik Analisis Bahasa: Pengantar Penelitian Wahana Kebudayaan secara Linguistis. Yogyakarta: Sanata Dharma University Press. 
Sugiyono. 2014. Memahami Penelitian Kualitatif. Bandung: Alfabeta.

Tekalp, Murat, Jörn Ostermann. 2000. Face and 2-D Mesh Animation in $M P E G-4$. Signal Processing: Image Communication. Vol. 15, No.4-5, hlm. 387-421.

Tim Pusat Humas Kementerian Perdagangan RI. 2014. Panduan Optimaslisasi Media Sosial Untuk Kementerian Perdagangan RI. Jakarta: Pusat Humas Kementerian Perdagangan RI.

\section{Sumber dari Internet}

Sav, Rage Comics, 2011, http://knowyourmeme.com/meme s/rage-comics diakses pada 27 Juni 2016.

NN, TT, www.memes.at diakses pada 8 November 2016.

$\mathrm{NN}$, www.instagram.com/9owar md7eka/ diakses pada 23 November 2016.

NN, TT, www.instagram-brand.com diakses pada 23 November 2016. 